Key Words:

MST

Actinides

Strontium

\title{
Demonstration of MST Efficacy on Removal of Actinides and Strontium in "Bounding Alpha" Waste
}

\author{
S. D. Fink \\ D. T. Hobbs \\ T. B. Peters
}

December 17, 2002

Westinghouse Savannah River Company

Savannah River Site

Aiken, SC 29808

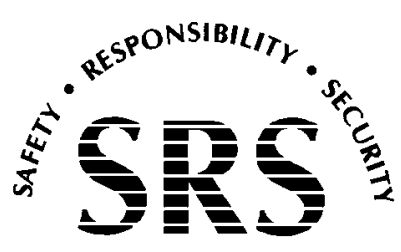

SAVANNAH RIVER SITE

Prepared for the U.S. Department of Energy Under

Contract Number DE-AC09-96SR18500 
This document was prepared in conjunction with work accomplished under Contract No. DE-AC09-96SR18500 with the U. S. Department of Energy.

\section{DISCLAIMER}

This report was prepared as an account of work sponsored by an agency of the United States Government. Neither the United States Government nor any agency thereof, nor any of their employees, makes any warranty, express or implied, or assumes any legal liability or responsibility for the accuracy, completeness, or usefulness of any information, apparatus, product or process disclosed, or represents that its use would not infringe privately owned rights. Reference herein to any specific commercial product, process or service by trade name, trademark, manufacturer, or otherwise does not necessarily constitute or imply its endorsement, recommendation, or favoring by the United States Government or any agency thereof. The views and opinions of authors expressed herein do not necessarily state or reflect those of the United States Government or any agency thereof.

This report has been reproduced directly from the best available copy.

Available for sale to the public, in paper, from: U.S. Department of Commerce, National Technical Information Service, 5285 Port Royal Road, Springfield, VA 22161, phone: (800) 553-6847, fax: (703) 605-6900

email: orders@ntis.fedworld.gov

online ordering: http://www.ntis.gov/help/index.asp

Available electronically at http://www.osti.gov/bridge

Available for a processing fee to U.S. Department of Energy and its contractors, in paper, from: U.S. Department of Energy, Office of Scientific and Technical Information, P.O. Box 62, Oak Ridge, TN 37831-0062,

phone: (865)576-8401,

fax: (865)576-5728

email: $\underline{\text { reports@ adonis.osti.gov }}$ 
WSRC-TR-2002-00555

\section{List of Abbreviations}

$\begin{array}{ll}\text { ADS } & \text { Analytical Development Section } \\ \text { AMP } & \text { Ammonium Molybdophosphate } \\ \text { DF } & \text { Decontamination Factor (= starting concentration/ending concentration) } \\ \text { DL } & \text { Detection Limit } \\ \text { DU } & \text { Depleted Uranium } \\ \mathrm{HLW} & \text { High Level Waste } \\ \mathrm{MnO}_{4}^{-} & \text {Permanganate } \\ \mathrm{MST}_{\mathrm{Np}} & \text { Monosodium Titanate } \\ \text { Pu } & \text { Neptunium } \\ \text { PuTTa } & \text { Plutonium } \\ \text { RADICPMS } & \text { Plutonium triphenoyltrifluoroacetone extraction } \\ \text { SRTC } & \text { Savannah River Technology Center } \\ \text { SWPF } & \text { Salt Waste Processing Facility } \\ \text { U } & \text { Uranium } \\ \text { WAC } & \text { Waste Acceptance Criteria } \\ \text { WPTS } & \text { Waste Processing Technology Section }\end{array}$


WSRC-TR-2002-00555

\subsection{Executive Summary}

Previous work at SRS identified five macrobatches of waste projected to fail to meet removal requirements for total alpha after treatment with monosodium titanate (MST) at the baseline conditions proposed for the Salt Waste Processing Facility (SWPF). This document describes an experimental demonstration that examined removal of strontium and alpha emitting radionuclides from a composite of several tanks present in the most limiting macrobatches. The work investigated the amount of MST needed to treat this "bounding alpha" macrobatch composite such that the separated liquid can meet the Salt Waste Processing Facility limits. The experiments show the following results.

- Plutonium removal behavior gives Decontamination Factor (DF) that agreed well with pre-test expectations.

- Plutonium removal to meet current SWPF requirements for this "bounding" waste requires $1.2 \mathrm{~g} / \mathrm{L}$ (i.e., $3 \mathrm{X}$ the baseline) MST.

- Alpha decontamination using 1.2 g/L of MST would meet the proposed new Saltstone Waste Acceptance Criteria (WAC).

- Strontium removal met the current SWPF specification with the baseline treatment using $0.4 \mathrm{~g} / \mathrm{L}$ MST.

- Neptunium was sufficiently removed to meet the SWPF requirement using $0.4 \mathrm{~g} / \mathrm{L}$ MST.

- Uranium removal increased with increasing MST concentration. Uranium removal is not a factor in meeting the SWPF limits on total alpha.

\subsection{Introduction}

In the last 10 years, SRTC personnel studied the ability of MST to sorb a variety of elements, such as Sr, Np, U, and Pu. Previous work at SRTC examined the specifics of MST sorption. ${ }^{1,2,3,4,5,6,7,7,9,10}$ During FY01, personnel developed the projected blending plan for the facility defining 67 macrobatches and estimated MST performance for removing $\mathrm{Sr}$ and $\mathrm{Pu}$ from these batches. ${ }^{11}$ The projections identified five batches - SPT002, SPT-008, SPT-065, SPT-066, and SPT-067 - for which a single addition of MST at $0.4 \mathrm{~g} / \mathrm{L}$ may not meet process objectives at the proposed operating conditions. The two most limiting macrobatches, SPT-008 and SPT-066, consist of waste blended from Tanks $21 \mathrm{H}, 26 \mathrm{~F}, 33 \mathrm{~F}$, and $39 \mathrm{H}$. The customer requested that SRTC experimentally determine 
whether or not MST could meet performance requirements with these bounding wastes. ${ }^{12,13}$

Personnel obtained and analyzed samples from these four tanks. Analyses for macrobatch SPT-008 did not prove the most limiting as shown in the following section. Hence, the management team opted to proceed with a demonstration using a composite of all the samples. To this composite, researchers added MST at three intervals and monitored removal of strontium and actinides as a function of time.

\subsection{Experimental Detail}

We received salt solution from Tanks $21 \mathrm{H}, 26 \mathrm{~F}, 33 \mathrm{~F}$, and $39 \mathrm{H}$. We analyzed each of these tank wastes for the pertinent radioisotopes (Appendix 1). After analyses, the researchers consulted with the management team. The team, along with the consent of the customer, decided to combine all four of the salt solutions (except for archival samples) into a single composite. From the measurements of the individual tank samples, the composite was estimated to be at $5.6 \mathrm{M}$ sodium; no dilution or concentration was required. At the time, activity estimates of the composite indicated that the composite would prove more challenging than the most limiting macrobatch, SPT-008. After combining the salt solutions, the researchers analyzed the composite at two times over a period of two weeks ("Composite 1 week" and "Composite 2 week") to ensure that the actinides and strontium equilibrated after mixing. Although the results between the two different times differed somewhat, the researchers judged that the actinides and strontium had equilibrated. Table 1 lists the activities of the macrobatches and the composites.

Table 1. Radioisotope Concentration in Each of the Salt Solutions.

\begin{tabular}{|c|c|c|c|c|c|c|}
\hline Sample & $\begin{array}{c}{ }^{238} \mathbf{P u} \\
\mathbf{n C i} / \mathbf{g}\end{array}$ & $\begin{array}{c}\mathbf{2 3 9 / 2 4 0} \mathbf{P u} \\
\mathbf{n C i} / \mathbf{g}\end{array}$ & $\begin{array}{c}{ }^{\mathbf{9 0}} \mathbf{S r} \\
\mathbf{n C i} / \mathbf{g}\end{array}$ & $\begin{array}{c}{ }^{237} \mathbf{N p} \\
\mathbf{n C i} / \mathbf{g}\end{array}$ & $\begin{array}{c}\mathbf{2 3 5} / \mathbf{2 3 8} \mathbf{U} \\
\mathbf{n C i} / \mathbf{g}\end{array}$ & $\begin{array}{c}\text { Total Alpha } \\
\mathbf{n C i} / \mathbf{g}\end{array}$ \\
\hline $\begin{array}{c}\text { Est .Macrobatch } \\
\text { SPT-008 }\end{array}$ & 8.29 & 1.20 & $2.29 \mathrm{E}+02$ & $<8.98 \mathrm{E}-02$ & 0.00330 & 9.49 \\
\hline $\begin{array}{c}\text { Est. Macrobatch } \\
\text { SPT-066 }\end{array}$ & $6.67 \mathrm{E}+02$ & $1.27 \mathrm{E}+01$ & $1.14 \mathrm{E}+03$ & $<4.73 \mathrm{E}-01$ & $3.70 \mathrm{E}-03$ & 679 \\
\hline Est. Composite & $3.87 \mathrm{E}+02$ & $8.03 \mathrm{E}+00$ & $7.59 \mathrm{E}+02$ & $<3.01 \mathrm{E}-01$ & $3.95 \mathrm{E}-03$ & 395 \\
\hline Composite 1 week & $6.37 \mathrm{E}+02$ & $9.13 \mathrm{E}+00$ & $2.11 \mathrm{E}+03$ & $<3.95 \mathrm{E}-01$ & $4.70 \mathrm{E}-03$ & 646 \\
\hline Composite 2 week & $3.72 \mathrm{E}+02$ & $3.85 \mathrm{E}+00$ & $3.85 \mathrm{E}+02$ & $<3.99 \mathrm{E}-01$ & $2.91 \mathrm{E}-03$ & 376 \\
\hline Time 0 Control & $4.78 \mathrm{E}+02$ & $1.22 \mathrm{E}+01$ & $4.15 \mathrm{E}+02$ & $5.90 \mathrm{E}-02$ & $3.90 \mathrm{E}-03$ & 490 \\
\hline
\end{tabular}

We measured the activities in each case, except in the "macrobatch" entries. In that case, we calculated the activities using our measured values where available, and measured values from the High Level Waste System Plan. ${ }^{15}$ See Appendix 2 for details. 
The SRTC estimates of the activities of each of the radioisotopes in the composite turned out to be reasonably close to the measured values by the time of the third (Time $=0$ Control) sample. Differences were most likely due to complex actinide and strontium chemistry (dissolution and precipitation during mixing and equilibrium) occurring between soluble and insoluble species.

After preparing the composite, technicians dispensed $100 \mathrm{~mL}$ each into three $125-\mathrm{mL}$ polyethylene bottles. We used two of the bottles to conduct the MST experiments, while one bottle served as a control. We added $0.4 \mathrm{~g} / \mathrm{L}$ of MST (from lot 33180) to the two reaction bottles at intervals of 0,30 , and 54 hours. During the experiment, personnel collected samples from each of the three bottles at 0, 4, 24, 30, 54, and 78 hours. (For samples at 0,30 , and 54 hours, sampling occurred immediately prior to MST addition.) Throughout the course of the experiment, the bottles were agitated using a magnetic stir plate and stir bars.

Technicians filtered the samples using $0.45 \mu \mathrm{m}$ syringe filters, diluted them with acid, removed them from the cells for analysis, and analyzed for uranium, neptunium (RADICPMS), plutonium (PuTTa), and strontium (Beta scintillation).

\subsection{Results of Investigations}

\subsection{Plutonium Results}

Researchers analyzed the filtered solutions for total plutonium $\left({ }^{238} \mathrm{Pu}+{ }^{239 / 240} \mathrm{Pu}\right)$. Table 2 shows these plutonium results while Figure 1 shows the graphical results.

Table 2. Total Plutonium concentrations In the Filtrate.

\begin{tabular}{|c|c|c|c|c|}
\hline & Experiment $\mathrm{A}$ & Experiment B & Exp. A/B & Control \\
\hline Time (hours) & Total $\mathrm{Pu}(\mathrm{nCi} / \mathrm{g})$ & Total $\mathrm{Pu}(\mathrm{nCi} / \mathrm{g})$ & Standard Dev. & Total Pu $(\mathrm{nCi} / \mathrm{g})$ \\
\hline $0^{*}$ & 490 & 490 & NA & 490 \\
\hline 4 & 132 & 133 & 0.489 & 481 \\
\hline 24 & 77.2 & 79.3 & 1.50 & 458 \\
\hline 30 & 77.2 & 78.7 & 1.05 & 478 \\
\hline 54 & 23.8 & $<25.9$ & NA & 451 \\
\hline 78 & 14.9 & $<16.5$ & NA & 481 \\
\hline
\end{tabular}

$*$ The time $=0$ data are the same data point.

The data from the duplicate reactions compared quite well. Figure 1 plots the total plutonium data for the two duplicate experiments and the control over time. Figure 1 also shows the Salt Waste Processing Facility process requirement for total alpha 
Figure 1. Total Plutonium in Solution Over Time.

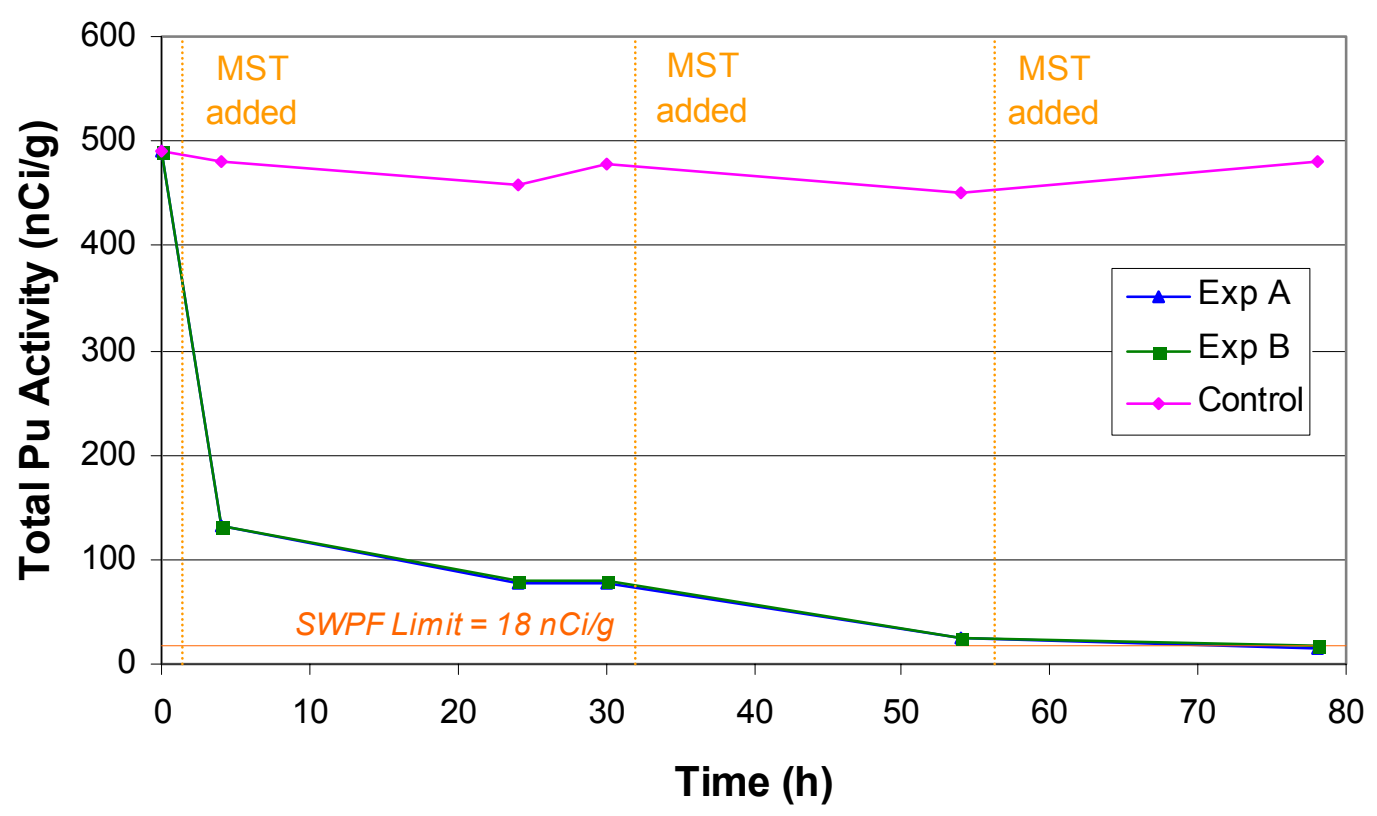

removal $(18 \mathrm{nCi} / \mathrm{g})$. As this experiment involved three MST consecutive strikes, we can calculate a stepwise DF value for each addition. Table 3 lists the DF values after each strike. As one would expect, increasing MST addition brings diminishing returns.

Table 3. Total Plutonium Decontamination Factors After Each MST Addition.

\begin{tabular}{|c|c|c|c|c|}
\hline $\begin{array}{c}\text { Time After } \\
\text { MST addition }\end{array}$ & $\begin{array}{c}\text { Total } \\
\text { Hours }\end{array}$ & $\begin{array}{c}\text { DF Value, } \\
\text { Exp. A }\end{array}$ & $\begin{array}{c}\text { DF Value, } \\
\text { Exp. B }\end{array}$ & Average DF \\
\hline 30 & 30 & 6.3 & 6.2 & 6.2 \\
\hline 24 & 54 & 3.0 & 2.9 & 2.9 \\
\hline 24 & 78 & 1.7 & 1.6 & 1.6 \\
\hline
\end{tabular}

From the plutonium data we note that by 24 hours after the third MST strike, the total plutonium in solution fell below the SWPF total alpha limits of $18 \mathrm{nCi} / \mathrm{g}$. If regulatory approval occurs for the proposed new Saltstone WAC the total alpha limit will increase to $99 \mathrm{nCi} / \mathrm{g}$. If this is the case, our data shows that within 24 hours of a single MST strike, the total alpha would fall within the revised WAC limits. 
WSRC-TR-2002-00555

\subsection{Strontium Results}

Researchers analyzed the filtered solutions for strontium-90. Table 4 shows the numerical values while Figure 2 shows the graphical results.

Table 4. Strontium-90 Concentrations in the Filtrate.

\begin{tabular}{|c|c|c|c|c|}
\hline Time (hours) & Exp. A & Exp. B & Exp. A/B & Control \\
\hline & ${ }^{90} \mathrm{Sr}(\mathrm{nCi} / \mathrm{g})$ & ${ }^{90} \mathrm{Sr}(\mathrm{nCi} / \mathrm{g})$ & Standard Dev. & ${ }^{90} \mathrm{Sr}(\mathrm{nCi} / \mathrm{g})$ \\
\hline $0^{*}$ & $4.15 \mathrm{E}+02$ & $4.15 \mathrm{E}+02$ & NA & $4.15 \mathrm{E}+02$ \\
\hline 4 & $1.40 \mathrm{E}+01$ & $2.32 \mathrm{E}+01$ & 6.47 & $3.76 \mathrm{E}+02$ \\
\hline 24 & $1.25 \mathrm{E}+01$ & $1.14 \mathrm{E}+01$ & 0.790 & $5.88 \mathrm{E}+02$ \\
\hline 30 & $3.05 \mathrm{E}+01$ & $6.56 \mathrm{E}+01$ & 24.9 & $4.06 \mathrm{E}+02$ \\
\hline 54 & $1.81 \mathrm{E}+01$ & $1.05 \mathrm{E}+01$ & 5.37 & $3.66 \mathrm{E}+02$ \\
\hline 78 & $<8.04 \mathrm{E}+00$ & $3.41 \mathrm{E}+01$ & NA & $3.98 \mathrm{E}+02$ \\
\hline
\end{tabular}

$*$ The time $=0$ data are the same data point.

The data points from the duplicate reactions showed fair amount of deviation, notably at Time $=30$. The control showed a single large deviation for the 24-hour samples but otherwise behaved reasonably well. This may be due to contamination in the cells. We cannot determine a standard deviation from the Time $=78$ data points as one of them fell below detection limits. This data point is marked with an "*” on the graph to indicate they represent upper bounds.

Figure 2. Strontium in Solution Over Time.

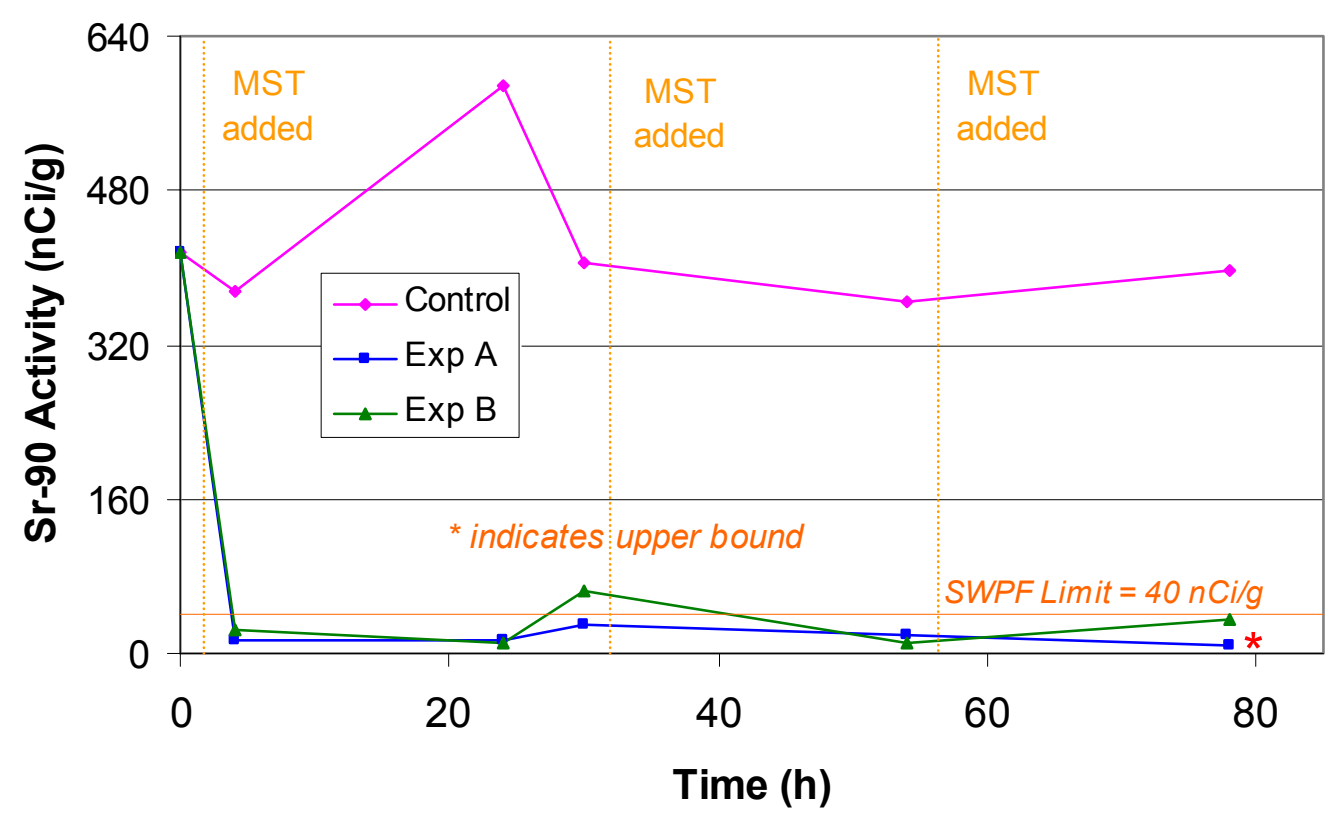


The data shows that with a single MST addition, the strontium in solution drops below the Salt Waste Processing Facility requirement of $40 \mathrm{nCi} / \mathrm{g} .{ }^{14}$ As this experiment involved three MST consecutive strikes, we can calculate a stepwise DF value for each addition. Table 5 lists the DF values after each strike. In the case of Experiment A, the 78 hour data point fell below the detection limit, so we can only calculate a minimal DF value.

Table 5. Strontium Decontamination Factors After Each MST Addition.

\begin{tabular}{|c|c|c|c|c|}
\hline $\begin{array}{c}\text { Time After } \\
\text { MST addition }\end{array}$ & $\begin{array}{c}\text { Total } \\
\text { Hours }\end{array}$ & $\begin{array}{c}\text { DF Value, } \\
\text { Exp. A }\end{array}$ & $\begin{array}{c}\text { DF Value, } \\
\text { Exp. B }\end{array}$ & Average DF \\
\hline 30 & 30 & 13.6 & 6.33 & 9.97 \\
\hline 24 & 54 & 1.69 & 6.25 & 3.97 \\
\hline 24 & 78 & $>2.25$ & 0.31 & NA \\
\hline
\end{tabular}

We also analyzed the solution for non-radioactive strontium. To detect the small amounts of cold strontium, we struck a sample of the bounding waste composite with AMP (ammonium molybdophosphate - a cesium removal agent) so we could avoid having to dilute the sample for ALARA reasons. The analysis showed that the bounding waste composite had cold strontium at $90.2 \mathrm{ppb}$ (compared to the mass of ${ }^{90} \mathrm{Sr}$ of 3.82 $\mathrm{ppb}$ ). Therefore we can conclude that even in the face of a large excess of cold strontium, the MST was still effective in removing the radioactive strontium.

\subsection{Neptunium Results}

Researchers analyzed the filtered solutions for neptunium-237. Table 6 shows the numerical values while Figure 3 shows the graphical results.

Table 6. Neptunium-237 Concentrations in the Filtrate.

\begin{tabular}{|c|c|c|c|c|}
\hline Time (hours) & Exp. A & Exp. B & Exp. A/B & Control \\
\hline & ${ }^{237} \mathrm{~Np}(\mathrm{nCi} / \mathrm{g})$ & ${ }^{237} \mathrm{~Np}(\mathrm{nCi} / \mathrm{g})$ & Standard Dev. & ${ }^{237} \mathrm{~Np}(\mathrm{nCi} / \mathrm{g})$ \\
\hline $0^{*}$ & $5.90 \mathrm{E}-02$ & $5.90 \mathrm{E}-02$ & NA & $5.90 \mathrm{E}-02$ \\
\hline 4 & $2.58 \mathrm{E}-02$ & $2.66 \mathrm{E}-02$ & $5.07 \mathrm{E}-04$ & $6.11 \mathrm{E}-02$ \\
\hline 24 & $2.04 \mathrm{E}-02$ & $<1.43 \mathrm{E}-02$ & NA & $6.99 \mathrm{E}-02$ \\
\hline 30 & $1.70 \mathrm{E}-02$ & $1.43 \mathrm{E}-02$ & $1.92 \mathrm{E}-03$ & $5.72 \mathrm{E}-02$ \\
\hline 54 & $<1.45 \mathrm{E}-02$ & $<1.44 \mathrm{E}-02$ & NA & $6.59 \mathrm{E}-02$ \\
\hline 78 & $<2.01 \mathrm{E}-02$ & $<1.34 \mathrm{E}-02$ & NA & $7.33 \mathrm{E}-02$ \\
\hline
\end{tabular}

* The time $=0$ data are the same data point.

A number of the neptunium sample results fell below detection limits. For experiment A, the 54 and 78 hour data points fell below the detection level. For experiment B, the 24, 54 , and 78 hour data points fell below the detection limit. These data points are marked 
with a "*" on the graph to indicate they are upper bounds. For this same reason we could not calculate standard deviation for those points. For the two replicate values, the calculated standard deviation showed good agreement.

Figure 3. Neptunium in Solution Over Time.

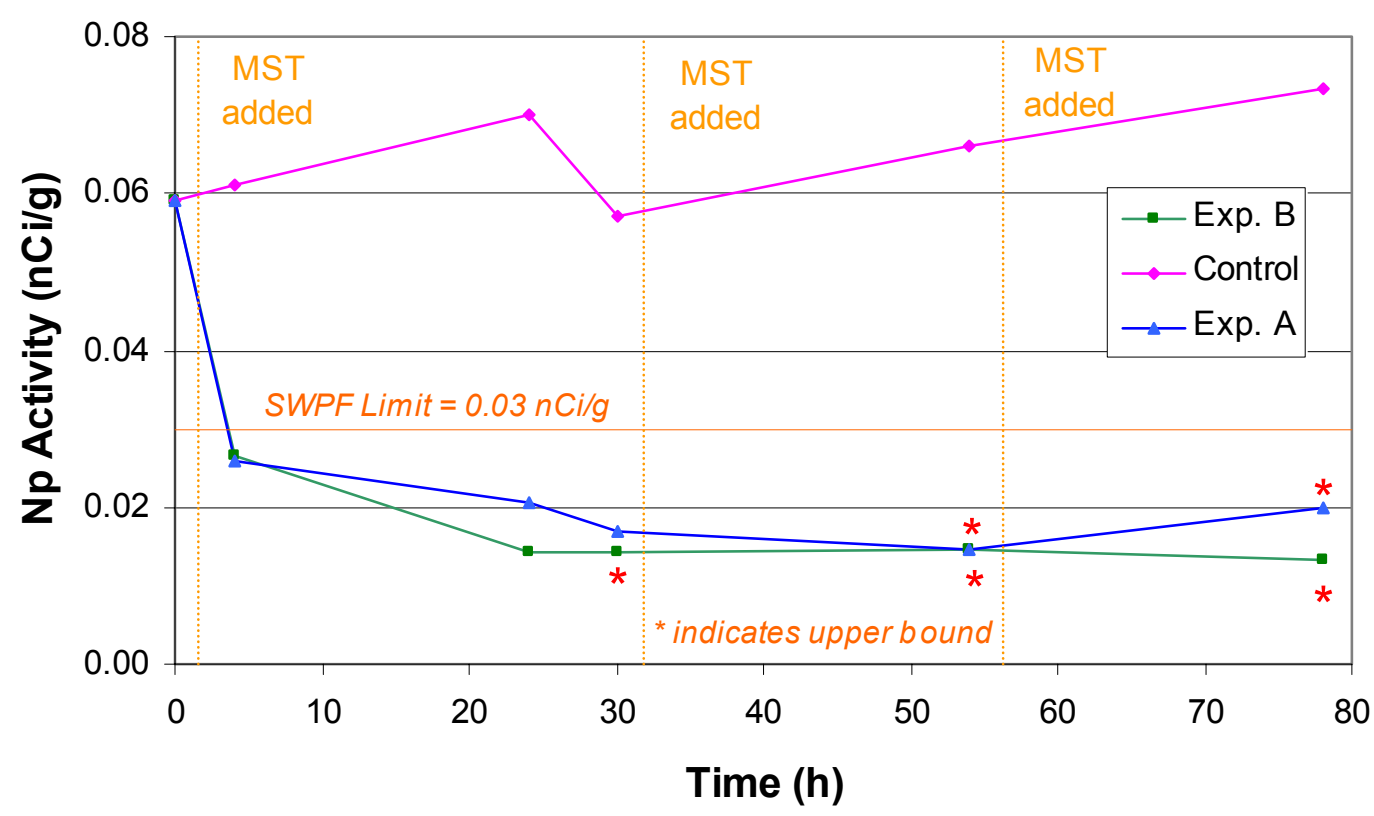

As this experiment involved three MST consecutive strikes, we can calculate a stepwise DF value for each addition. Table 7 lists the DF values after each strike. In the case of both experiments, the 54 hour data points fell below the detection limit, so we can only calculate a minimal DF value in each case. Additionally, the 78 hour data points for both

Table 7. Neptunium Decontamination Factors After Each MST Addition.

\begin{tabular}{|c|c|c|c|c|}
\hline $\begin{array}{c}\text { Time After } \\
\text { MST addition }\end{array}$ & $\begin{array}{c}\text { Total } \\
\text { Hours }\end{array}$ & $\begin{array}{c}\text { DF Value, } \\
\text { Exp. A }\end{array}$ & $\begin{array}{c}\text { DF Value, } \\
\text { Exp. B }\end{array}$ & Average DF \\
\hline 30 & 30 & 3.5 & 4.1 & 3.8 \\
\hline 24 & 54 & $>1.2$ & $>1.0$ & NA \\
\hline 24 & 78 & NA & NA & NA \\
\hline
\end{tabular}

experiments fell below the detection limits, which prevents us from calculating a DF value. A total DF of $\sim 4$ occurred, reducing the neptunium levels to within Salt Waste Processing Facility requirements $(<0.03 \mathrm{nCi} / \mathrm{g})$. 
WSRC-TR-2002-00555

\subsection{Uranium Results}

Researchers analyzed the filtered solutions for uranium-235 and -238. Table 8 shows the numerical values while Figure 4 shows the graphical results. The time $=54$ sample for Experiment A clearly represents a contamination of the archive sample in the cells. We reached this conclusion since reanalysis of the both the original samples as well as of

Table 8. Total Uranium $(235+238)$ concentration in filtrate.

\begin{tabular}{|c|c|c|c|c|}
\hline Time (hours) & Exp. A & Exp. B & Exp. A/B & Control \\
\hline & Total U (nCi/g) & Total U (nCi/g) & Standard Dev. & Total U (nCi/g) \\
\hline $0^{*}$ & $3.90 \mathrm{E}-03$ & $3.90 \mathrm{E}-03$ & NA & $3.90 \mathrm{E}-03$ \\
\hline 4 & $3.14 \mathrm{E}-03$ & $2.95 \mathrm{E}-03$ & $1.38 \mathrm{E}-04$ & $3.55 \mathrm{E}-03$ \\
\hline 24 & $2.87 \mathrm{E}-03$ & $2.68 \mathrm{E}-03$ & $1.30 \mathrm{E}-04$ & $3.49 \mathrm{E}-03$ \\
\hline 30 & $3.20 \mathrm{E}-03$ & $3.01 \mathrm{E}-03$ & $1.34 \mathrm{E}-04$ & $3.63 \mathrm{E}-03$ \\
\hline 54 & $8.49 \mathrm{E}-03$ & $2.09 \mathrm{E}-03$ & $4.27 \mathrm{E}-03$ & $3.30 \mathrm{E}-03$ \\
\hline 78 & $1.84 \mathrm{E}-03$ & $1.71 \mathrm{E}-03$ & $8.97 \mathrm{E}-05$ & $3.82 \mathrm{E}-03$ \\
\hline
\end{tabular}

* The time $=0$ data are the same data point.

new samples of the archived material show the same uranium values. Other than this data point, the duplicate experiments agreed well. The uranium concentration in the control remained constant throughout the time of the experiments.

Figure 4. Total Uranium $(235+238)$ in Solution Over Time.

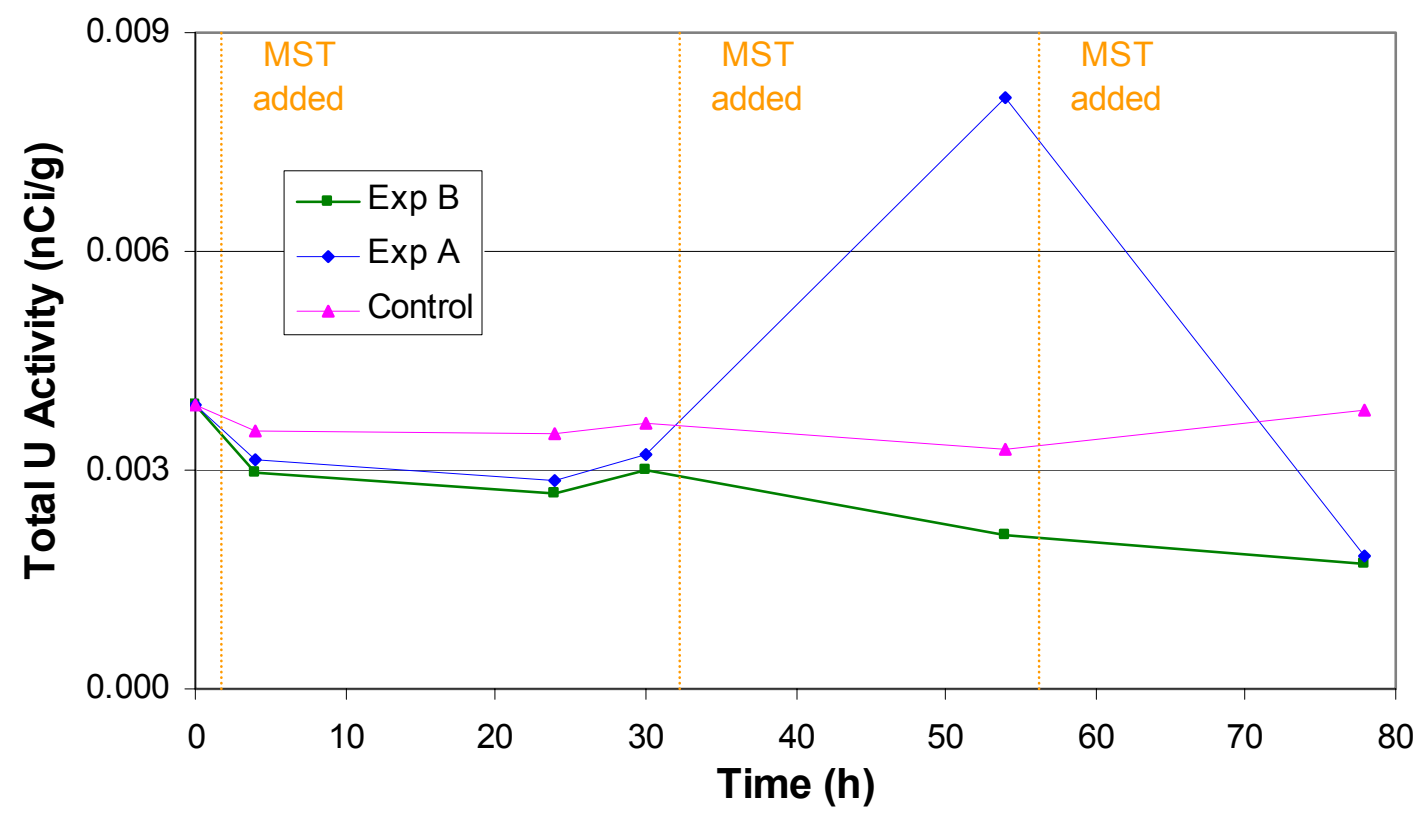


As this experiment involved three MST consecutive strikes, we can calculate a stepwise DF value for each addition. Table 9 lists the DF values after each strike. Due to the Time $=54$ hour contaminated data point for Experiment A, we cannot calculate a DF value for either the second or third MST strike.

Table 9. Uranium Decontamination Factors After Each MST Addition.

\begin{tabular}{|c|c|c|c|c|}
\hline $\begin{array}{c}\text { Time After } \\
\text { MST addition }\end{array}$ & $\begin{array}{c}\text { Total } \\
\text { Hours }\end{array}$ & $\begin{array}{c}\text { DF Value, } \\
\text { Exp. A }\end{array}$ & $\begin{array}{c}\text { DF Value, } \\
\text { Exp. B }\end{array}$ & Average DF \\
\hline 30 & 30 & 1.2 & 1.3 & 1.2 \\
\hline 24 & 54 & NA & 1.4 & NA \\
\hline 24 & 78 & NA & 1.2 & NA \\
\hline
\end{tabular}

All the MST strikes proved effective in removing the uranium. The total DF of $\sim 2$ agrees with expectations from prior tests. The SWPF does not have a removal requirement for uranium.

\subsection{Conclusions}

- We prepared a "bounding alpha" waste composite from samples from Tanks $21 \mathrm{H}$, $26 \mathrm{~F}, 33 \mathrm{~F}$, and $39 \mathrm{H}$ that had high levels of plutonium, strontium, neptunium and uranium. After equilibrium, this composite proved more limiting than macrobatch SPT008, but not as limiting as macrobatch SPT066.

- Three MST strikes of $0.4 \mathrm{~g} / \mathrm{L}$ each reduced the total plutonium to below the current SWPF process requirement of $18 \mathrm{nCi} / \mathrm{g}$.

- A single MST strike reduced the strontium-90 activity to below the SWPF process requirement of $40 \mathrm{nCi} / \mathrm{g}$.

- A single MST strike reduced the neptunium-237 activity to below the Salt Waste Processing Facility requirement of $0.03 \mathrm{nCi} / \mathrm{g}$.

- The uranium behavior agreed with expectations from prior testing. 
Appendix 1. Solution Composition of the Tank Samples and the Composite.

\begin{tabular}{|c|c|c|c|c|c|}
\hline Analysis & \begin{tabular}{|l|} 
Tank 21H \\
(HTK-475)
\end{tabular} & $\begin{array}{l}\text { Tank 26F } \\
\text { (FTF-096, } \\
-102) \\
\end{array}$ & $\begin{array}{l}\text { Tank 33F } \\
\text { (FTF-107) }\end{array}$ & $\begin{array}{l}\text { Tank 39H } \\
\text { (HTF-E-146, } \\
-147,-148)\end{array}$ & Composite \\
\hline Pu-238 (nCi/g) & $1.69 \mathrm{E}+01$ & $5.55 \mathrm{E}+00$ & $1.30 \mathrm{E}+01$ & $8.38 \mathrm{E}+02$ & $3.72 \mathrm{E}+02$ \\
\hline Pu-239/240 (nCi/g) & $1.68 \mathrm{E}+00$ & $7.18 \mathrm{E}-01$ & $2.19 \mathrm{E}+00$ & $1.59 \mathrm{E}+01$ & $3.85 \mathrm{E}+00$ \\
\hline Sr-90 (nCi/g) & $1.97 \mathrm{E}+02$ & $3.44 \mathrm{E}+02$ & $3.13 \mathrm{E}+01$ & $1.43 \mathrm{E}+03$ & $3.85 \mathrm{E}+02$ \\
\hline Np-237 (nCi/g) & $<3.19 \mathrm{E}-03$ & $<1.46 \mathrm{E}-01$ & $<4.37 \mathrm{E}-03$ & $<5.92 \mathrm{E}-01$ & $<3.99 \mathrm{E}-01$ \\
\hline $\mathrm{U}-235 / 238(\mathrm{nCi} / \mathrm{g})$ & $3.27 \mathrm{E}-03$ & $3.45 \mathrm{E}-03$ & $3.38 \mathrm{E}-03$ & $4.65 \mathrm{E}-03$ & 2.93E-03 \\
\hline Total Alpha (nCi/g) & 18.58 & 6.27 & 15.19 & 853.91 & 375.85 \\
\hline Cs-137 (nCi/g) & $1.12 \mathrm{E}+03$ & $9.44 \mathrm{E}+05$ & $6.76 \mathrm{E}+03$ & $6.66 \mathrm{E}+05$ & $5.12 \mathrm{E}+05$ \\
\hline $\mathrm{Al}(\mathrm{mg} / \mathrm{L})$ & NA & NA & NA & NA & 6894.4 \\
\hline $\mathrm{OH}^{-}(\mathbf{M})$ & NA & NA & NA & NA & 2.23 \\
\hline $\mathrm{CO}_{3}{ }^{2-}(\mathrm{M})$ & NA & NA & NA & NA & $<0.50$ \\
\hline $\operatorname{Ag}(\mathrm{mg} / \mathrm{L})$ & NA & NA & NA & NA & $<1.24$ \\
\hline $\operatorname{As}(\mathrm{mg} / \mathrm{L})$ & NA & NA & NA & NA & $<6.2$ \\
\hline $\mathrm{Ba}(\mathrm{mg} / \mathrm{L})$ & NA & NA & NA & NA & $<0.74$ \\
\hline Cd (mg/L) & NA & NA & NA & NA & 1.98 \\
\hline $\operatorname{Cr}(\mathrm{mg} / \mathrm{L})$ & NA & NA & NA & NA & 92.75 \\
\hline $\mathrm{Hg}(\mathrm{mg} / \mathrm{L})$ & NA & NA & NA & NA & $<27.28$ \\
\hline $\mathrm{Na}(\mathrm{mg} / \mathrm{L})$ & 20147 & 261023 & 69149 & 133504 & 118048 \\
\hline $\mathrm{Pb}(\mathrm{mg} / \mathrm{L})$ & NA & NA & NA & NA & $<11.41$ \\
\hline Se (mg/L) & NA & NA & NA & NA & $<6.20$ \\
\hline $\mathrm{Cl}(\mathrm{mg} / \mathrm{L})$ & NA & NA & NA & NA & 223.2 \\
\hline F (mg/L) & NA & NA & NA & NA & $<496$ \\
\hline formate $(\mathrm{mg} / \mathrm{L})$ & NA & NA & NA & NA & $<2480$ \\
\hline nitrate $(\mathrm{mg} / \mathrm{L})$ & NA & NA & NA & NA & 115816 \\
\hline nitrite (mg/L) & NA & NA & NA & NA & 28024 \\
\hline oxalate $(\mathrm{mg} / \mathrm{L})$ & NA & NA & NA & NA & $<2480$ \\
\hline phosphate (mg/L) & NA & NA & NA & NA & $<2480$ \\
\hline sulfate $(\mathrm{mg} / \mathrm{L})$ & NA & NA & NA & NA & 4216 \\
\hline
\end{tabular}

$\mathrm{NA}=$ not analyzed for 
WSRC-TR-2002-00555

\section{Appendix 2. Macrobatch Activity Estimates.}

To estimate the macrobatch activities, we referred to the HLW system plan ${ }^{15}$ to find the composition of each macrobatch.

Macrobatch SPT-008

The plan identified Macrobatch SPT-008 as containing the most alpha emitters.

Macrobatch SPT-008 has the estimated following composition in the HLW System Plan.

\begin{tabular}{|c|c|}
\hline Tank & Volume (gallons) \\
\hline Heel & 20,434 \\
\hline $21 \mathrm{H}$ & 70,000 \\
\hline $26 \mathrm{~F}$ & 730,000 \\
\hline $33 \mathrm{~F}$ & 367,419 \\
\hline $50 \mathrm{H}$ & 20,000 \\
\hline
\end{tabular}

Using these volume ratios and measured tank data, SRTC estimated the activity of each of the major radioisotopes of concern. Tank $21 \mathrm{H}, 26 \mathrm{~F}$, and $33 \mathrm{~F}$ measured values came from our own recent measurements, while we used a measured value provided by HLW for the Tank $50 \mathrm{H}$ activity (zero for the listed species). We assumed the heel and inhibited water activities as zero for all radioisotopes.

\begin{tabular}{|c|c|c|c|c|c|c|}
\hline \multirow[b]{3}{*}{ Isotope } & \multicolumn{5}{|c|}{ Activites in $\mathrm{nCi} / \mathrm{g}$} & \multirow{3}{*}{$\begin{array}{l}\text { Macrobatch Activity } \\
\mathrm{nCi} / \mathrm{g}\end{array}$} \\
\hline & \multicolumn{3}{|c|}{ SRTC measured } & \multicolumn{2}{|c|}{ HLW values } & \\
\hline & Tank 21 & Tank 26 & Tank 33 & Tank 50 & heel & \\
\hline Pu-238 & $1.69 \mathrm{E}+01$ & $5.55 \mathrm{E}+00$ & $1.30 \mathrm{E}+01$ & $0.00 \mathrm{E}+00$ & $0.00 \mathrm{E}+00$ & $8.29 \mathrm{E}+00$ \\
\hline Pu-239/240 & $1.68 \mathrm{E}+00$ & 7.18E-01 & $2.19 E+00$ & $0.00 \mathrm{E}+00$ & $0.00 \mathrm{E}+00$ & $1.20 \mathrm{E}+00$ \\
\hline$U-235 / 238$ & $3.27 \mathrm{E}-03$ & $3.45 \mathrm{E}-03$ & $3.38 \mathrm{E}-03$ & $0.00 \mathrm{E}+00$ & $0.00 \mathrm{E}+00$ & $3.30 \mathrm{E}-03$ \\
\hline Np-237 & 3.19E-03 & 1.46E-01 & 4.37E-03 & $0.00 \mathrm{E}+00$ & $0.00 \mathrm{E}+00$ & 8.98E-02 \\
\hline Sr-90 & $1.97 \mathrm{E}+02$ & $3.44 \mathrm{E}+02$ & $3.13 E+01$ & $0.00 \mathrm{E}+00$ & $0.00 \mathrm{E}+00$ & $2.29 \mathrm{E}+02$ \\
\hline volume (gal) & 70000 & 730,000 & 367419 & 20000 & 20434 & \\
\hline
\end{tabular}

The neptunium measurement is actually less than or equal to the value shown (detection limits).

\section{Macrobatch SPT-066}

The plan identified Macrobatch SPT-066 as containing the second most limiting alpha concentration. That batch has the estimated following composition.

\begin{tabular}{|c|c|}
\hline Tank & Volume (gallons) \\
\hline Heel & 20,620 \\
\hline $39 \mathrm{H}$ & 980,000 \\
\hline Inhibited water & 230,000 \\
\hline
\end{tabular}


Using these volume ratios and measured tank data, SRTC estimated the activity of each of the major radioisotopes of concern. Tank $39 \mathrm{H}$ measured values came from our own recent measurements. We assume the heel and inhibited water activity as zero for all radioisotopes.

\begin{tabular}{|c|c|c|c|c|}
\hline \multirow[b]{3}{*}{ Isotope } & \multicolumn{3}{|c|}{ Activites in $\mathrm{nCi} / \mathrm{g}$} & \multirow{3}{*}{$\begin{array}{l}\text { Macrobatch Activity } \\
\text { nCi/g }\end{array}$} \\
\hline & \multirow{2}{*}{$\begin{array}{c}\text { SRTC measured } \\
\text { Tank } 39 \mathrm{H}\end{array}$} & \multicolumn{2}{|c|}{ HLW values } & \\
\hline & & inhib water & heel & \\
\hline Pu-238 & $8.38 \mathrm{E}+02$ & $0.00 \mathrm{E}+00$ & $0.00 \mathrm{E}+00$ & $6.67 \mathrm{E}+02$ \\
\hline Pu-239/240 & $1.59 \mathrm{E}+01$ & $0.00 E+00$ & $0.00 E+00$ & 1.27E+01 \\
\hline U-235/238 & 4.65E-03 & $0.00 E+00$ & $0.00 E+00$ & 3.70E-03 \\
\hline Np-237 & 5.93E-01 & $0.00 E+00$ & $0.00 E+00$ & 4.73E-01 \\
\hline Sr-90 & $1.43 E+03$ & $0.00 \mathrm{E}+00$ & $0.00 \mathrm{E}+00$ & $1.14 \mathrm{E}+03$ \\
\hline volume (gal) & 980,000 & 230000 & 20620 & \\
\hline
\end{tabular}

The neptunium measurement is actually less than or equal to the value shown (detection limits).

As it turns out, Macrobatch SPT-066 proves much more limiting than SPT-008. 
WSRC-TR-2002-00555

\subsection{References}

${ }^{1}$ D. T. Hobbs and D. D. Walker, "Plutonium and Uranium Adsorption on Monosodium Titanate," WSRC-RP-92-93, August 13, 1992.

${ }^{2}$ D. T. Hobbs and S. D. Fleischman, "Fissile Solubility and Monosodium Titanate Loading Tests," WSRC-RP-92-1273, February 12, 1993.

${ }^{3}$ M. J. Barnes, D. T. Hobbs, M. C. Duff, and S. D. Fink, "Strontium and Actinides Removal from Savannah River Site Actual Waste Samples by Freshly Precipitated Manganese Oxide," WSRC-TR-2002-00048, Rev. 2, August 12, 2002.

${ }^{4}$ M. G. Bronikowski, D. T. Hobbs, and W. R. Wilmarth, "Preliminary Report on Monosodium Titanate Adsorption Kinetics," WSRC-TR-98-00347, Rev. 0, October 5, 1998.

${ }^{5}$ D. T. Hobbs, M. G. Bronikowski, T. B. Edwards, and R. L. Pulmano, "Final Report on Monosodium Titanate Adsorption Kinetics," WSRC-TR-99-0134, Rev. 0, May 28, 1999.

${ }^{6}$ D. T. Hobbs and R. L. Pulmano, "Phase IV Simulant Testing of Monosodium Titanate Adsorption Kinetics," WSRC-TR-99-0219, Rev. 0, June 29, 1999.

${ }^{7}$ D. T. Hobbs and R. L. Pulmano, "Phase IV Testing of Monosodium Titanate Adsorption Kinetics with Radioactive Waste," WSRC-TR-99-00286, Rev. 0, September 3, 1999.

${ }^{8}$ R. A. Dimmena, H. H. Elder, J. R. Fowler, R. C. Fowler, M. V. Gregory, T. Hang, R. A. Jacobs, P. K. Paul, J. A. Pike, P. L. Rutland, F. G. Smith III, S. G. Subosits, G. A. Taylor and S. G. Campbell, "Bases, Assumptions, and Results of the Flowsheet Calculations for the Short List Salt Disposition Alternatives," WSRC-RP-99-00006, Rev. 3, May, 2001.

${ }^{9}$ D. T. Hobbs, M. S. Blume and H. L. Thacker, "Phase V Simulant Testing of Monosodium Titanate Adsorption Kinetics," WSRC-TR-2000-00142, Rev. 0, May 24, 2000.

${ }^{10} \mathrm{D}$ T. Hobbs, "Evaluation of Alternate Materials and Methods for Strontium and Alpha Removal from Savannah River Site High Level Waste Solutions," WSRC-TR-200000229, August 2000.

${ }^{11}$ H. H. Elder, "Salt Blending Basis for Revision 12 of the HLW System Plan", HLWSDT-2001-00146, Rev. 0, April 2001.

12 "Program Execution Guidance for WSRC Salt Processing", Subtask A, Task 2, TTP \# SR01WT21, September 17, 2001.

${ }^{13}$ T. B Peters, "Task Technical and Quality Assurance Plan for Alpha and Strontium Removal in Bounding Waste using Monosodium Titanate", WSRC-RP-2001-01031, December 4, 2001. 
WSRC-TR-2002-00555

${ }^{14}$ F. A. Washburn, "SRS Soluble HLW Characterization", HLW-SDT-2001-00310 Rev. 1, December 28, 2001.

15 "Savannah River Site High Level Waste System Plan: Revision 12," HLW-200100040, March 2001. 